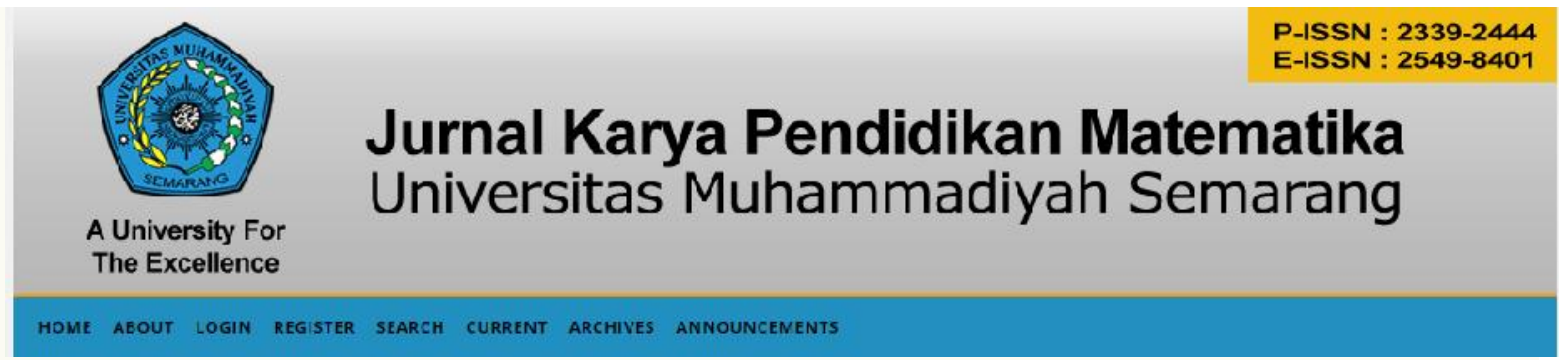

\title{
PENGARUH KEDISIPLINAN SISWA TERHADAP PRESTASI BELAJAR SISWAKELAS X-IPA SMA NEGERI 15 SEMARANG
}

\author{
Dra.Sri Wigati \\ Guru Matematika SMA N 15 Semarang \\ email: dra.wigati@gmail.com
}

\begin{tabular}{ll}
\hline \multicolumn{2}{l}{ Article history } \\
\hline Submission & $: 13 / 11 / 2018$ \\
Revised & $: 2 / 2 / 2019$ \\
Accepted & $: 4 / 4 / 2019$
\end{tabular}

Keyword: Discipline,

Learning Achievement.

Kata kunci: Kedisiplinan,

Prestasi Belajar.

\begin{abstract}
Education of the generation of the nation, especially the younger generation, is one of the things that must be considered in order to improve and develop the Indonesian nation. All parties related to the achievement of educational success must cooperate. Starting from the school, parents, government, or the community. One of the successes of education can be seen from learning achievement. In terms of learning, discipline is one of the factors that must be considered. Based on observations made by researchers at Semarang State High School 15, there are still many students who still violate school rules. Therefore, researchers want to know the effect of discipline on student learning outcomes. The research sample was 60 students from 252 students of class X-IPA. The method of data collection is done by using questionnaires and observations. The results of this study indicate that student discipline on student achievement is very influential and it can be seen that the average student discipline is 3.1 which includes the Very Good (SB) category. The Very Good categorized average is directly proportional to student achievement results with an average of 82.
\end{abstract}




\section{PENDAHULUAN}

Peranan dan Pendidikan generasi muda di Indonesia sangat penting untuk diperhatikan. Generasi muda merupakan pondasi yang harus disiapkan demi membangun bangsa yang berkualitas yang mampu bersaing dengan bangsa lain. Pengembangan diri generasi muda dapat diperbaiki melalui pendidikan. Sudah sepantasnya jika keberhasilan pendidikan harus diperhatikan baik dari pemerintah, orang tua maupun masyarakat demi terwujudnya cita-cita bangsa.

Seperti yang tertuang dalam pasal 4 UndangUndang Sistem Pendidikan Nasional menjelaskan bahwa tujuan Pendidikan Nasional Depdiknas,1998:7 dalam (Aini:2015) adalah “ Pendidikan nasional bertujuan mencerdaskan kehidupan bangsa dan mengembangkan manusia Indonesia seutuhnya,yaitu manusia yang beriman dan bertaqwa terhadap Tuhan Yang Maha Esa dan berbudi pekerti luhur, memiliki pengetahuan dan ketrampilan, kesehatan jasmani dan rohani, kepribadian yang mantap dan mandiri serta rasa tanggungjawab kemasyarakatan dan kebangsaan

Pendidikan pada anak yang berhasil akan mencitpakan investasi bangsa demi perkembangan dan peningkatan suatu bangsa. Keberhasilan pendidikan yang terdapat dalam sekolah dapat dilihat dari hasil prestasi belajar. Hasil dari pembelajaran yang ada disekolah dapat menentukan keberhasilan pendidikan dapat berjalan dengan baik ataupun tidak.

Prestasi belajar adalah hasil yang telah dicapai oleh seseorang setelah mengerjakan suatu hal untuk memperoleh perubahan prilaku secara terus menerus berdasarkan pengalamannya sendiri dan tidak terjadi secara genetik (sariasih:2014).

Faktor yang mempengaruhi prestasi belajar terdapat dua faktor yaitu faktor internal (bersumber dalam diri siswa sendiri) dan faktor eksternal (bersumber di luar siswa). Salah satu faktor ekternal yang dapat mempengaruhi siswa yaitu kedisiplinan. Kedisiplinan dapat mempengaruhi prestasi belajar karena ketika siswa tidak disiplin dalam proses belajar maka akan berakibat nigatif pada hasil belajar mereka.

Berdasarkan observasi yang kami lakukan di SMA Negeri 15 Semarang, masih banyak siswa yang melanggar tata tertib sekolah yang telah ditentukan. Pelanggaran yang dilakukan siswa misalnya tidak memakai perlengkapan sekolah sesuai aturan, terlamabat masuk sekolah,tidak masuk kelas pada saat guru belum memasuki kelas saat jam peajaran, berpotongan rambut yang tidak sesuai aturan, bahkan ada siswa yang asik dengan laptop untuk menonton film saat guru menyuruh siswa lainnya mempresentasikan hasil diskusi siswa.

Berdasarkan observasi tersebut dikhawatirkan jika masalah tersebut tidak diperhatikan, prestasi belajar siswa tidak mempunyai hasil yang baik dan tentunya dari prestasi belajar yang tidak baik tersebut dapat menggambarkan bahwa pendidikan memiliki hasil yang kurang baik yang nantinya dapat menghambat terciptanya tujuan pendidikan yaitu demi neningkatkan kualitas bangsa. Berdasarkan latar belakang tersebut peneliti ingin mengetahui pengaruh kedisiplinan siswa terhadap prestasi belajar siswa.

\section{KAJIAN TEORETIK}

Menurut Kamus Besar Bahasa Indonesia, pendidikan merupakan proses perubahan sikap dan tata laku seseorang atau kelompok orang dalam usaha mendewasakan manusia melalui upaya pengajaran dan pelatihan, proses, cara dan perbuatan mendidik.

Menurut Undang-Undang SISDIKNAS No.20 Tahun 2003 menyatakan pendidikan merupakan usaha sadar dan terencana untuk mewujudkan suasana belajar dan proses pembelajaran agar peserta didik secara aktif mengembangkan potensi dirinya untuk memiliki kekuatan spiritual, keagamaan, pengendalian diri, kepribadian, kecerdasan, ahlak mulia, serta keteramplan yang diperlukan dirinya dan masyarakat.

John Stuart Mill filosof Inggris, 1806-1873 dalam (siregar dkk:2014) menjabarkan bahwa Pendidikan itu meliputi segala sesuatu yang dikerjakan oleh seseorang untuk dirinya atau yang dikerjakan oleh orang lain untuk dia, dengan tujuan mendekatkan dia kepada tingkat kesempurnaan.

Menurut Edgar Dalle dalam (siregar dkk: 2013) berpendapat bahwa pendidikan merupakan usaha sadar yang dilakukan oleh keluarga, masyarakat, dan pemerintah melalui kegiatan bimbingan, pengajaran, dan latihan, yang berlangsung di sekolah dan di luar sekolah sepanjang hayat untuk mempersiapkan peserta didik agar dapat mempermainkan peranan dalam berbagai lingkungan hidup secara tetap untuk masa yang akan datang.

Maka dapat disimpulkan bahwa pendidikan merupakan suatu proses yang dikerjakan seseoang atau kelompok untuk 
meningkatkan potensi diri untuk tercapainya kemampuan yang sempurna demi mempersiapkan masa yang akan datang.

Menurut Undang-Undang SISDIKNAS

No.20 Tahun 2003 Pendidikan nasional berfungsi mengembangkan kemampuan dan membentuk watak serta peradaban bangsa yang bermartabat dalam rangka mencerdaskan kehidupan bangsa, bertujuan untuk berkembangnya potensi peserta didik agar menjadi manusia yang beriman dan bertakwa kepada Tuhan Yang Maha Esa, berakhlak mulia, sehat, berilmu, cakap, kreatif, mandiri, dan menjadi warga negara yang demokratis serta bertanggung jawab.

Berdasarkan tujuan dan Fungsi pendidikan yang dicantumkan dalam UndangUndang SISDIKNAS No.20 Tahun 2003 BAB II Pasal 3, maka dengan adanya pendidikan dapat membantu perkembangan bangsa. Untuk mengetahui pembelajaran dalam meningkatkan hasil pendidikan yang baik, maka dapat dilihat dari hasil prestasi belajar siswa.

Prestasi belajar menurut Poerwadarminta 2007:910 dalam (Sariasih:2014) menyatakan prestasi adalah hasil yang telah dicapai (dilakukan, dikerjakan, dan sebagainya) dalam suatu hal. Menurut Kamus Besar Bahasa Indonesia Prestasi adalah hasil yang dicapai setelah melakukan atau mengerjakan sesuatu.

Maka prestasi belajar merupakan hasil yang diperoleh setelah melakukan suatu hal pembelajaran yang akan menunjang peningkatan pengalaman dan perubahan tingkah laku.

Keberhasilan untuk meningkatkan hasil belajar dapat dipengaruhi beberapa faktor baik dari faktor yang menunjang maupun faktor yang bersifat menghambat . Faktor yang mempengaruhi prestasi belajar ada 2 kelompok yaitu faktor intern dan faktor ektern. Faktor intern merupakan faktor yang mempengaruhi prestasi belajar dari dalam diri individu sendiri, sedangkan faktor ektern merupakan faktor yang berasal dari luar individu.

Kedisiplinan merupakan salah satu faktor ekstern yang telah mempegaruhi prestasi belajar. Disiplin menurut Kamus Besar Bahasa Indonesia, kata disiplin berarti tata tertib (disekolah kemiliteran), ketaatan (kepatuhan) pada peraturan.

Menurut Ahmad Rohani dan Abu Ahmadi dalam (Ilyas:2008) disiplin adalah mencakup setiap macam peraturan yang ditunjukkan untuk membantu stiap peserta didik agar dia dapat memenuhi dan menyesuaikan diri dengan lingkungannya dan juga penting tentang penyelesaiannya tuntunan yang ini ditunjukan kepada peserta didik terhadap lingkungannya. Disiplin menurut Amir Achin dalam (Ilyas:2008) merupakan pematuhan secara sadar akan aturan-aturan yang telah ditetapkan.

Berdasarkan beberapa pengertian disiplin yang telah dijelaskan, maka dapat disimpulan bahwa disiplin adalah menjalankan, mentaati dan patuh terhadap peraturan atau tata tertib yang sudah ditetapkan demi tercapainya tujuan yang telah ditetapkan.

\section{METODOLOGI PENELITIAN}

Penelitian ini dilaksanakan di SMA Negeri 15Semarang pada bulan Februari 2019. Subjek penelitian ini adalah siswa kelas X-IPA di SMA Negeri 15 Semarang dan pengambil sampel sebanyak 60 siswa dari 252 siswa yang kelas X-IPA. Sampel merupakan sebagian dari keseluruhan subjek yang digunakan untuk diteliti.

Pendekatan yang digunakan pada penelitian ini adalah pendekatan kualitatif yangmana dengan pendekatan ini, penelitian ditunjukkan dengan cara mendiskripsikan dan mengawasi dari peristiwa atau kegiatan, mendiskripsikan pendapat dari personal atau kelompok. Menurut Suandhi 2006:3 dalam (Sriasih:2014) menyatakan bahwa penelitian kualitatif adalah penelitian yang dimaksudkan untuk mengungkapkan gejala secara holistikkontekstual melalui pengumpulan data dari latar alami dengan memanfaatkan diri peneliti sebagai instrumen kunci.

Maka penelitian dengan pendekatan kualitatif merupakan penelitian yang ditunjukkan dengan cara mendiskripsikan dari pengawasan suatu peristiwa, pendapat individu maupun kelompok yang digunakan sebagai data untuk membuat suatu penelitian.

Metode pengumpulan data dalam penelitian ini dengan cara pengumpulan data angket kedisiplinan dan pengumpulan nilai hasil prestasi siswa. Selain dengan pengumpulan data angket, pengumpulan data penelitian ini juga dilakukan dengan cara obsevasi.

\section{HASIL DAN PEMBAHASAN PENELITIAN Hasil Penelitian}

Penelitian ini dikelompokkan menjadi dua bagian, yaitu terdiri dari kelompok data 
variabel terikat yaitu, hasil belajar siswa, dan data variabel bebas disiplin belajar yang dideskripsikan dalam bentuk deskriptif statistik.

\section{Diagram 1. Diagram Kedisiplinan}

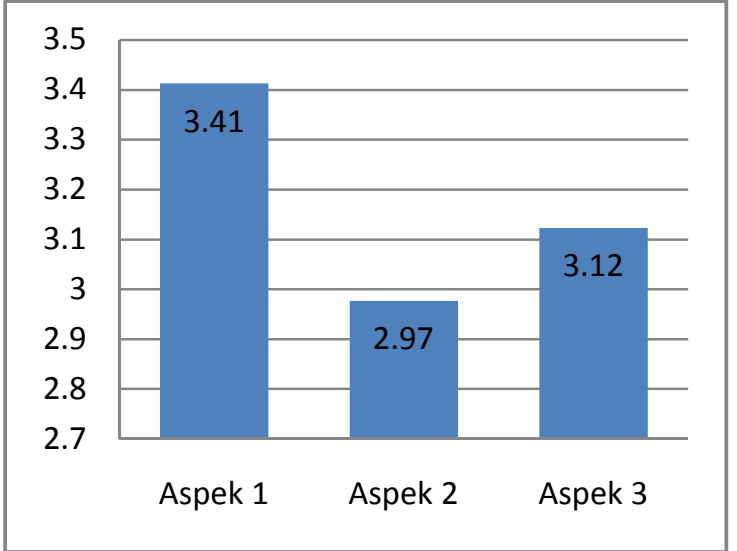

Pada variabel bebas terdiri 3 aspek. Aspek yang pertama adalah aspek ketaatan, aspek kedua adalah aspek ketepatan, dan aspek ketiga adalah aspek ketertiban. Setiap ratarata(x) aspek dibagi menjadi 4 kategori. Kategori pertama $\mathrm{x} \leq 1$ adalah Tidak Baik (TB), kategori kedua $\mathrm{x} \leq 2$ adalah Cukup Baik (CB), kategori ketiga $\mathrm{x} \leq 3$ adalah Baik (B), dan ketegori terakhir yaitu $\mathrm{x} \leq 4$ berarti Sangat Baik (SB). Kategori setiap indikator dari masing-masing aspek juga dikategorikan menjadi 4 bagian sama seperti kategori yang ada di kategori aspek.

Diagram 2. Aspek Ketaatan

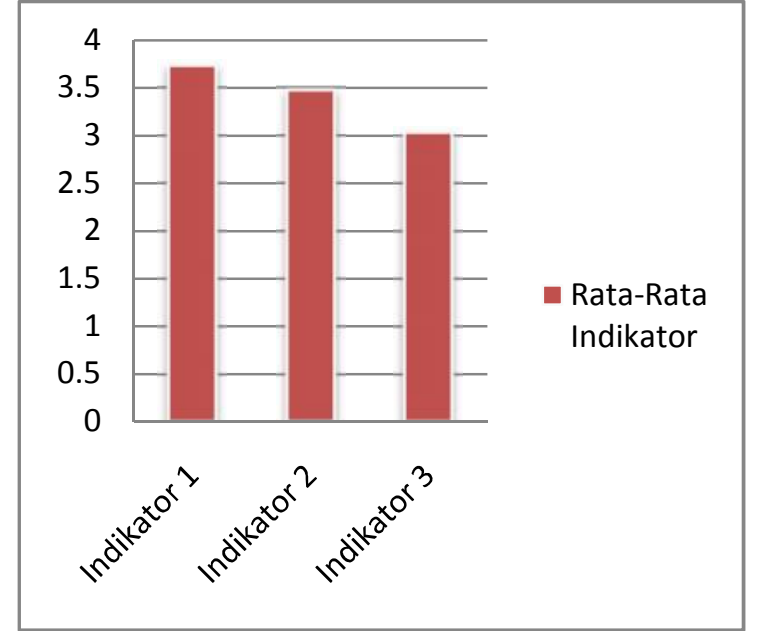

Aspek yang pertama adalah aspek ketaatan yang memiliki rata-rata 3,41 termasuk kategori Sangat Baik (SB). Aspek yang ketaatan ini dibagi menjadi 3 indikator. Idikator pertama taat terhadap tata tertib sekolah memiliki ratarata 3,73 dengan kategori Sangat Baik (SB). Indikator yang kedua yaitu taat terhadap kegiatan belajar di kelas yang memilikiratarata 3,47 dengan kategori Sangat Baik (SB). Indikator yang terakhir yaitu taat dalam mengerjakan tugas memiliki rata-rata 3,03 dengan kategori Sangat Baik (SB).

\section{Diagram.3 Aspek Ketepatan}

\section{Aspek Ketepatan}

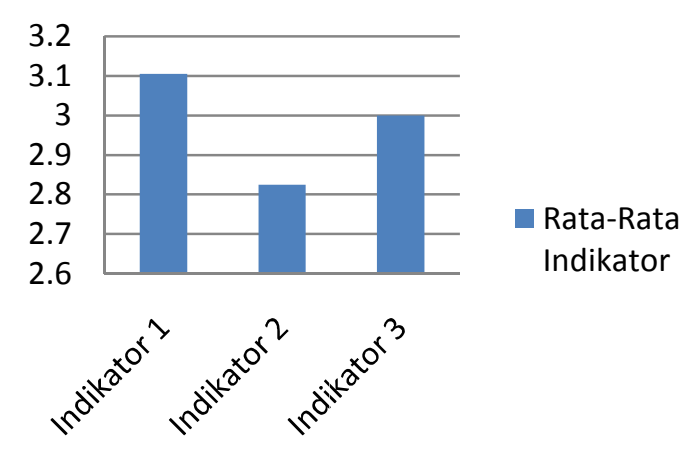

Aspek kedua dari kedisiplinan adalah ketepatan yang memiliki rata-rata 2,97 dengan keterangan Baik (B). Siswa akan dinilai ketepatannya dari ketiga idikator yaitu indikator selalu aktif dalam melakukan hal positif yang memiliki rata-rata 3,10 berarti memiliki kategori Sangat Baik (SB). Indikator yang kedua adalah mengerjakan hal yang telah direncanakan dengan baik. indikator yang kedua memiliki rata-rata 2,82 dengan keterangan Baik (B). Indikator ketiga adalah menghargai waktu memiliki rata-rata 3 dengan keterangan Baik (B).

\section{Diagram 4. Aspek Ketertiban}

\section{Aspek Ketertiban}

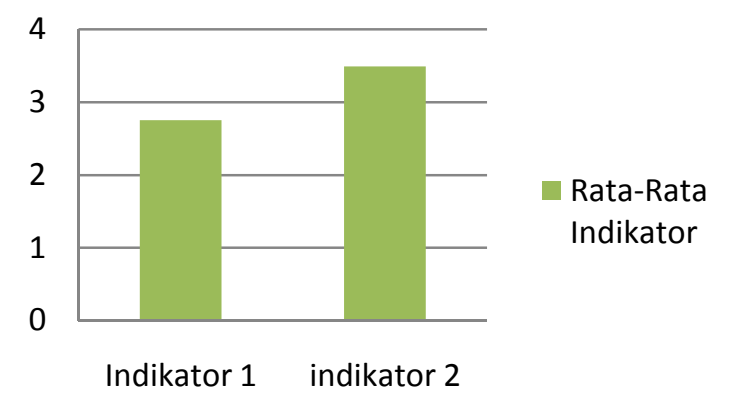

Pada aspek yang terakhir yaitu aspek ketertiban. Aspek ketertiban dibagi menjadi dua indikator. Indikator yang pertama adalah biasa bekerja secara tuntas dan tanggung jawab memiliki rata-rata 2,75 yang termasuk dalam kategori Baik (B). Indikator yang kedua adalah menghargai perarturan yang telah dibuat sekolah. Rata-rata pada indikator yang kedua ini 
ada 3,49 yang termasuk dalam kategori Sangat Baik (SB).

\section{Pembahasan}

Berdasarkan pengamatan sebelum penelitian di SMA Negeri 15 Semarang, hasil prestasi siswa yang satu dengan yang lainnya berbeda dikarenakan berbagai faktor. Hasil pengamatan yang dilakukan peneliti, maka peneliti melakukan penelitian untuk mengetahui apakah kedisiplinan siswa dapat mempengaruhi prestasi belajar pada mata pelajaran matematika.

Cara yang digunakan peneliti untuk mengetahui pengaruh kedisipinan siswa terhadap hasil belajar siswa yaitu dengan pengumpulan angket. Sedangkan untuk mengetahui prestasi belajar siswa dapat diketahui melalui rata-rata nilai

Berdasarkan hasil penelitian, untuk aspek ketaatan terhadap hasil belajar, terdapat delapan pernyataan tentang ketaatan siswa dalam melaksanakan tata tertib sekolah dan ketaatan dalam kegiatan belajar. Hasil rata-rata dari aspek ketaatan adalah 3,41 yang termasuk dalam kategori Sangat Baik (SB).

Berdasarkan hasil penelitian untuk aspek ketepatan terdapat Sembilan pernyataan tentang ketepatan dalam memanfaatkan waktu untuk hal positif. Hasil rata-rata dari aspek ketepatan adalah 2,97 yang termasuk dalam kategori Baik (B).

Sedangkan untuk aspek ketertiban terdapat enam pernyataan tentang melaksanakan kegiatan belajar dengan tertib secara tuntas dan tanggung jawab. Hasil ratarata dari aspek ketertiban adalah 3,12 yang termasuk dalam kategori Sangat Baik(SB).

Berdasarkan hasil rata-rata dari setiap aspek, aspek ketaatan yang memiliki nilai ratarata paling tinggi yaitu 3,41 . Sedangkan untuk aspek kedisiplinan yang memiliki rata-rata paling rendah yaitu aspek ketepatan yaitu dengan rata-rata 2,97 .

\section{KESIMPULAN DAN SARAN \\ Kesimpulan}

Hasil penelitian yang dilakukan peneliti dapat diambil kesimpulan bahwa kedisiplinan siswa X-IPA SMA Negeri 15 Semarang tahun ajaran 2018/2019 dapat mempengaruhi perestasi belajar. Hal tersebut dapat diketahui dari hasil rata rata 3,1 yang diketegorikan Sangat Baik dan berdasarkan dari rata-rata hasil prestasi siswa dengan responden 60 sebanyak 82. Jadi hal ini dapat menunjukkan bahwa kedidiplinan siswa SMA Negeri 15 Semarang dapat mempengaruhi prestasi belajar.

Saran

Setelah kegiatan penelitian dilaksanakan, ada beberapa saran yang diujukan untuk pihak pihak yang mempunyai kepentingan antara lain:

1. Kediplinan siswa dapat ditingkatkan dan dikembangkan dengan cara menanamkan peraturan atau kebiasaan untuk disiplin terhadap aturan sekolah.

2. Bagi para peneliti mendatang, diharapkan untuk memperhatikan apa yang menjadi keterbatasan maupun kekurangan dalam penelitian ini, sehingga penelitian yang akan datang dapat dilaksanakan secara baik dan dapat menghasilkan sesuatu yang mampu dipertanggungjawabkan.

\section{DAFTAR PUSTAKA}

Aini,Sri Nur.2015." Kedisiplinan Siswa, Motivasi Belajar Dan Peningkatan Prestasi Belajar PPKN Siswa".Banyuwangi.

Ilyas, Achmad Yani.2008."Pengaruh Disiplin Belajar Terhadap Pembentukan Perilaku Di MTS Nurul Falah Serpong".Jakarta.

Kamus besar bahasa Indonesia.

Sariasih,Nil Uh Putu.2013.” Penerapan

Pembelajaran Kooperatif Tipe STAD SebagaiUpaya Meningkatkan Aktivitas Dan Prestasi BelajarSiswa Dalam pembelajaran Bangun Datar Segi EmpatPada Siswa Kelas Viib Smp Negeri 3 ManggisTahun Pelajaran 2013/2014".Denpasar.

Undang Undang Republik Indonesia No 20 Tahun 2003 Tentang System Pendidikan Nasional 
